\title{
The effect of Moringa-treated wastewater on drip-irrigated sandy loam soil
}

\author{
A. Y. Arku ${ }^{1} \&$ S. M. Musa ${ }^{2}$ \\ ${ }^{I}$ Department of Agricultural and Environmental Resources Engineering, \\ University of Maiduguri, Nigeria \\ ${ }^{2}$ Agricultural and Bioresource Engineering Programme, \\ Abubakar Tafawa Balewa University (ATBU), Nigeria
}

\begin{abstract}
Moringa oleifera seeds possess coagulating and antimicrobial properties for wastewater treatment. This paper reports the chemical and biological analyses of wastewater samples from the university hostel $\left(\mathrm{W}_{1}\right)$, the main abattoir $\left(\mathrm{W}_{2}\right)$ and the Nigerian Bottling Company, $\mathrm{NBC}\left(\mathrm{W}_{3}\right)$ in Maiduguri, Nigeria; treated with Moringa seed solution concentration (MOSC) at 0 (Control), 10, 20, 30 and 40\% levels. The treated wastewater was used for irrigating Amaranthus hybridus under drip irrigation on sandy loam soil on the Agricultural and Environmental Resources Engineering Departmental Research Farm, University of Maiduguri. Initial coliform counts (CC) were measured as 1405,1571 and 1314 cells/100 $\mathrm{mL}$; the electrical conductivity (EC) values were $0.78,1.20$ and $1.23 \mathrm{dS} / \mathrm{m}$ and the sodium adsorption ratio (SAR) was $1.12,1.54$ and 1.18 . Similarly, the $\mathrm{pH}$ values were measured as 8.56, 5.60 and 6.98, while Boron (B) showed as 0.44 , 1.80 and 1.28 for $\mathrm{W}_{1}, \mathrm{~W}_{2}$ and $\mathrm{W}_{3}$ respectively. The initial soil conditions $\left(0_{\mathrm{i}}\right)$ were shown to contain CC $(28$ cells $/ 100 \mathrm{~mL}), \mathrm{EC}(0.69 \mathrm{dS} / \mathrm{m}), \mathrm{B}(0.63 \mathrm{mg} / \mathrm{L})$, $\mathrm{pH}(6.5), \mathrm{N}(10.71 \mathrm{mg} / \mathrm{L}), \mathrm{P}(10.42 \mathrm{mg} / \mathrm{L})$ and SAR (0.88). The results obtained indicate that the Moringa seed solution at $40 \%$ had an appreciable effect on most of the quality parameters in the irrigated soil when compared with the initial values.

Keywords: Amaranthus hybridus, drip irrigation, Moringa seed solution, quality, sandy loam, soil, water treatment.
\end{abstract}




\section{Introduction}

The immense pressure on and scarcity of fresh water due to rapid population growth has lead to challenges in water availability globally. Agriculture, being the largest consumer of fresh water, is that which is confronted the most with these challenges. Several strategies are currently being adopted in order to face these challenges. One of these strategies is the use of wastewater to supplement the deficits arising from fresh water shortages for crop irrigation. However, due to its health implications on the farmer and the consumer there is the need for wastewater treatment before use.

Health concerns have also been raised over the safety of the chemicals used. For example, inorganic coagulants and disinfectants such as alum $\left[\mathrm{K}_{2} \mathrm{SO}_{4} \cdot \mathrm{Al}_{2}\left(\mathrm{SO}_{4}\right)_{3} \cdot 24 \mathrm{H}_{2} \mathrm{O}\right]$ and chlorine $(\mathrm{Cl})$ have been found to be associated with the risks of cardiovascular diseases, cancers and birth defects. Such risks, though low, and the prevalence of these diseases should not be ruled out entirely (Bove et al. [1]).

Plant materials, though used for a long time, have not been able to favourably compete with the commonly used chemicals, which is largely due to insufficient knowledge about them (Kalibbala [2]). Researchers have worked on the effectiveness of a number of plants as coagulants. These include Cactus latifaira and Prosopis juliflora (Diaz et al. [3]), tannin from valonia (Özacar and Sengil [4]), apricot, peach kernel and beans (Jahn [5]). Bhole [6] discovered that maize and rice had good coagulation effects when used as primary coagulants. Chitosan, which has a high molecular weight polyelectrolyte derived from deacetylated chitin (cellulose-like biopolymer) and possesses effective coagulation properties, is also used in wastewater treatment and has antimicrobial properties (Davikaran and Pillai [7]). The advantages of using natural coagulants include the fact that quite reasonable savings in chemicals and sludge handling costs are reduced. For example, Al-Samawi and Shokrala [8] estimated that $50-90 \%$ of the alum requirement could be saved when okra was used as a primary coagulant or coagulant aid.

Moringa oleifera (Zogale in Hausa - a commonly used language in the study area and Drumstick in English) is a tropical tree that originates from India and is found in most tropical countries of Africa, Asia and Latin America (Sauveur and Peprah [9]). It has multiple uses and is drought-resistant but can adapt to most world climatic zones. Among the 14 species of Moringa known, Moringa oleifera is particularly easy to reproduce and it grows very fast. Moringa oleifera seeds (fig. 1) are round with a brownish semi-permeable seed hull. Foidl et al. [10] estimated that a Moringa tree can produce between 15,000 and 25,000 seeds/year.

The use of Moringa oleifera seeds for disinfection purposes has been reported by other researchers [11-13] and is considered very effective and a good alternative. In fact, water treatment plants that use Moringa Oleifera as a disinfectant in developing countries such as India, Malawi, Nicaragua and Senegal have been found to be saving foreign currency, thereby replacing or reducing chlorine and alum usage, which are considered expensive. Findings by 
Fuglie and Olivier [14] reveal that it has antimicrobial properties and does not significantly affect the $\mathrm{pH}$ level of the treated water (Sarpong and Richardson [15]). It is also useful in softening hard water and very effective in treating heavy metals in wastewater (Doerr [16]).

The mechanisms in Moringa seed actions are attributed to the water soluble, positively-charged protein that acts as an effective coagulant for wastewater treatment (Folklard and Sutherland [17]). In addition, such seed extracts are capable of bacterial aggregation and removal, with efficacy similar to that of aluminium salts and others commonly used as water treatment agents (Madsen et al. [18]). The sequence of one of these proteins was determined and shown to be a positively charged polypeptide (Tauscher [19]).

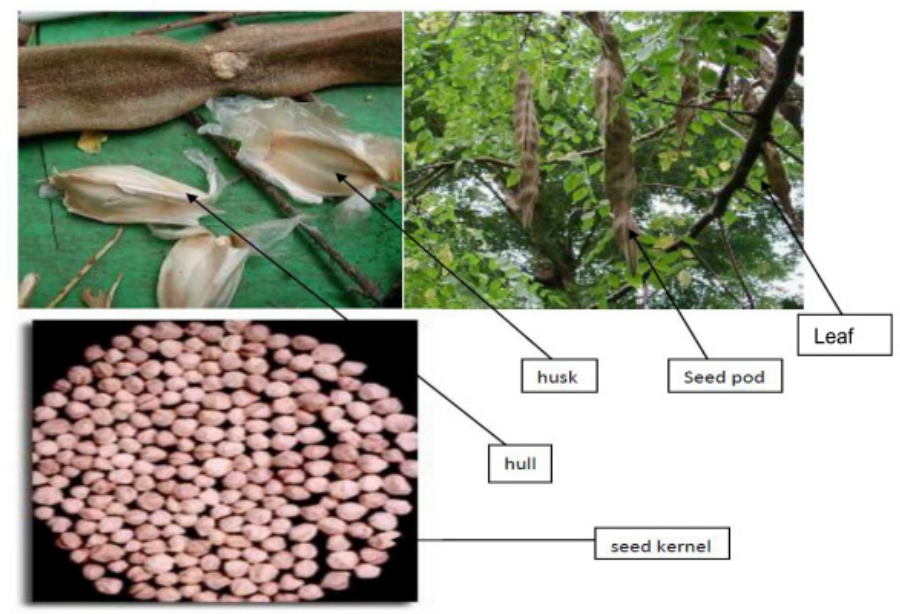

Figure 1: $\quad$ Parts of the Moringa oleifera tree.

In order to use Moringa seeds for wastewater treatment, it is necessary to use the appropriate dosage to get reasonable results. Schwarz [20] recommended a dosage based on the Moringa seed powder, as shown in Table 1.

Table 1: Recommended dosage of Moringa powder for wastewater treatment.

\begin{tabular}{|l|c|c|c|c|c|}
\hline $\begin{array}{l}\text { Turbidity } \\
\text { level, }\end{array}$ & NTU & Dosage, mg/L & NTU & \multicolumn{2}{|c|}{ Seeds } \\
\hline $\begin{array}{l}\text { Low } \\
\text { turbidity }\end{array}$ & $<50$ & $10-50$ & $<50$ & 1 & $\mathrm{~V}_{\mathrm{w}}, \mathrm{L}^{2}$ \\
\hline $\begin{array}{l}\text { Medium } \\
\text { turbidity }\end{array}$ & $50-150$ & $30-100$ & $50-150$ & 1 & 2.0 \\
\hline $\begin{array}{l}\text { High } \\
\text { turbidity }\end{array}$ & $>150$ & $50-200$ & $150-250$ & 1 & 1.0 \\
\hline $\begin{array}{l}\text { Extreme } \\
\text { turbidity }\end{array}$ & - & - & $>250$ & 2 & 1.0 \\
\hline
\end{tabular}

${ }^{1}$ Schwarz [20], ${ }^{2}$ Doerr [16]. 
Schwarz [20] was of the view that the application of a plant coagulant, such as Moringa oleifera, is highly recommended for domestic water purification in developing countries where people are prone to drinking contaminated turbid water. Schwarz was also of the opinion that Moringa does not guarantee that highly-polluted raw wastewater can be completely (100\%) free of pathogens. Similarly, Doerr [16] recommended dosages of Moringa seeds for treating specified wastewater volumes $\left(\mathrm{V}_{\mathrm{w}}\right)$, as shown in Table 1 .

\subsection{Objectives of the study}

Although most of the research work has been conducted on Moringa oleifera in the context of treating wastewater for domestic water use, this study sought to investigate its use for crop irrigation and more specifically, its effects on an irrigated sandy loam soil. The chemical and biological parameters were considered as priority because they come in direct contact with the crop when they filter into the soil.

\section{Methodology}

\subsection{The study area}

The research was conducted in Maiduguri (fig. 2), the capital of Borno state in northeastern Nigeria and lies between latitude $11^{\circ} 51^{\prime} \mathrm{N}$ and longitude $13^{\circ} 05^{\prime} \mathrm{E}$ at an altitude of $354 \mathrm{~m}$ above sea level. The city is known for its dryness, with a semi-arid climate, savannah or tropical grasslands vegetation and a light annual rainfall of about $300 \mathrm{~mm}$. Its average daily temperature ranges from 22 to $35^{\circ} \mathrm{C}$, sometimes with the mean of the daily maximum temperature exceeding $40^{\circ} \mathrm{C}$ between March and June before the onset of rains in July to September. It has mainly sandy loam soils. The wastewaters used for the experiment were each collected from the university hostel $\left(\mathrm{W}_{1}\right)$, the main abattoir $\left(\mathrm{W}_{2}\right)$ and the Nigerian Bottling Company, $\mathrm{NBC}\left(\mathrm{W}_{3}\right)$, all in Maiduguri, as shown in Figure 3. These wastewaters were predominately used untreated by the locals for irrigating their crops in the city. The Garmin's GPS (76 S Model) was used in determining the ordinates of the wastewater sources as indicated in Table 2.

Table 2: Types and sources of wastewaters.

\begin{tabular}{|c|c|c|c|c|}
\hline Type & Code & Source & Latitude & Longitude \\
\hline Domestic & $\mathrm{W}_{1}$ & $\begin{array}{l}\text { University } \\
\text { hostel }\end{array}$ & $11^{\circ} 48^{\prime} 15.3^{\prime \prime} \mathrm{N}$ & $13^{\circ} 12^{\prime} 10.4^{\prime \prime} \mathrm{E}$ \\
\hline Agricultural & $\mathrm{W}_{2}$ & Abattoir & $11^{\circ} 51^{\prime} 24.6^{\prime \prime} \mathrm{N}$ & $13^{\circ} 10^{\prime} 47.0^{\prime \prime} \mathrm{E}$ \\
\hline Industrial & $\mathrm{W}_{3}$ & $\begin{array}{l}\text { Nigerian } \\
\text { Bottling } \\
\text { Company }\end{array}$ & $11^{\circ} 50^{\prime} 58.7^{\prime \prime} \mathrm{N}$ & $13^{\circ} 05^{\prime} 38.9^{\prime \prime} \mathrm{E}$ \\
\hline
\end{tabular}




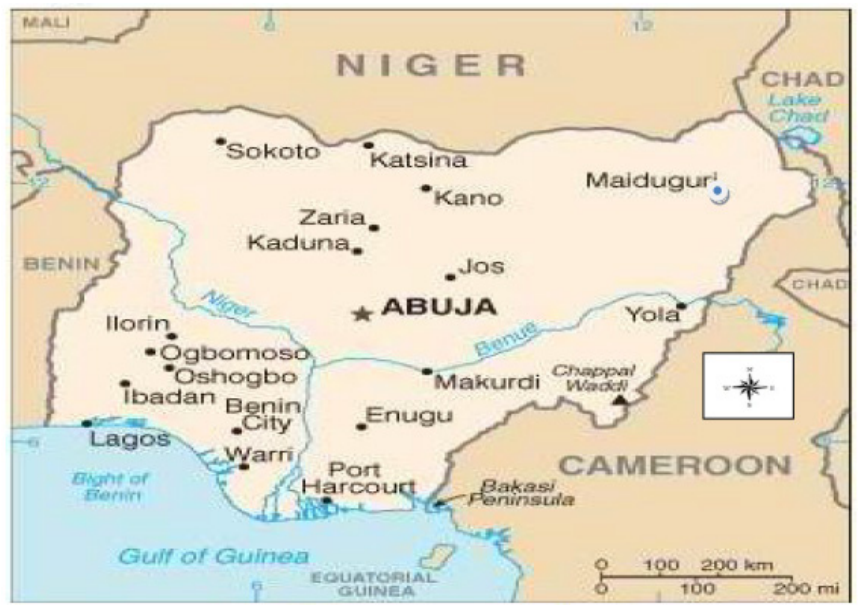

Figure 2: Location of Maiduguri city on a Nigerian map.

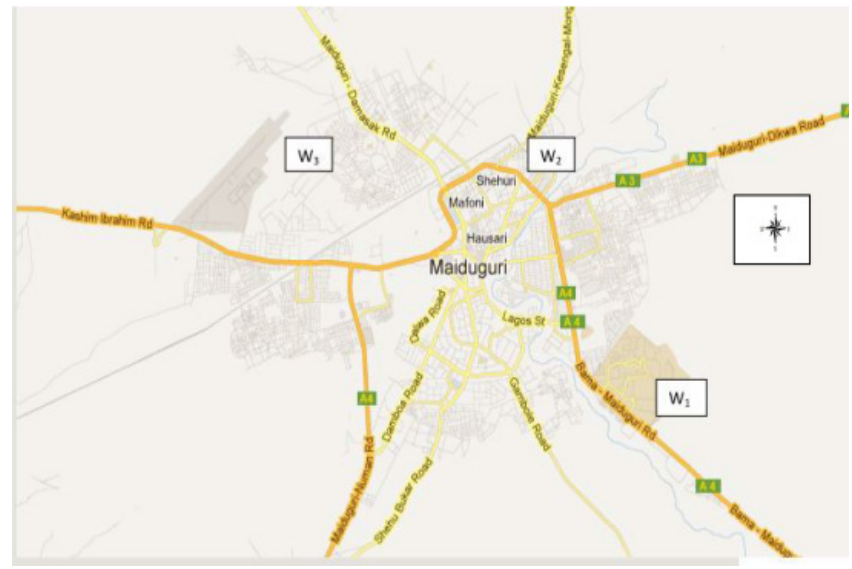

Figure 3: Maiduguri metropolis showing wastewater sources.

\subsection{Wastewater sampling methods}

A $25 \mathrm{~mm}$ PVC pipe was connected to the bathroom in the university hostel to collect domestic (grey) wastewater. Wastewater generated in the bathroom was then diverted and discharged through the pipe. For the agricultural wastewater, samples were collected from a point where local farmers used the water to pump to their vegetable farms. Although the wastewater discharged from the NBC plant is treated before it is discharged to an earth pond reservoir outside the company premises, over time it gets polluted due to some animal intrusion and other human activities. Sampling was conducted from the pond, at a fixed point, to minimize variations. 
For the abattoir and the Nigerian Bottling Company wastewaters, samples were collected from the top $100 \mathrm{~mm}$ depth. In all cases, a small plastic container was used to fill $50 \mathrm{~L}$ air-tight Jerry cans after being screened with a $0.1 \mathrm{~mm}$ stainless screen to prevent sediments. They were taken to the laboratory for analysis and subsequent utilization for irrigation. Water quality analysis using $1 \mathrm{~L}$ plastic bottles was conducted in the Geology Departmental Laboratory, University of Maiduguri, at room temperature ranging from 25 to $30^{\circ} \mathrm{C}$. Particle size analysis of the soil was obtained using the hydrometer method. In addition, gloves were used as protection against any contamination to the body.

\subsection{Crop water requirement and drip irrigation system}

The crop water requirement for the Amaranthus hybridus was determined using the climatic data in the study area for the Penman Monteith equation and the CROPWAT model as shown by Arku et al. [21]. The mean crop water required for the designed drip irrigation system layout (fig. 4) was $46.2 \mathrm{~L} /$ lateral/day with medi-emitters as described by Mofoke et al. [22]. Also, using Schwarz [20] and Doerr [16] standards as basis, a series of jar test trial experiments, as described by Arku et al. [23], were conducted to obtain standardized Moringa seed solution concentrations (Table 3). Soil samples were taken from the top $30 \mathrm{~mm}$ for analysis using appropriate methods (Table 4) after each 60-day seasonal growth period observed for the Amaranthus plant from January 01-June 30, 2010. This is the zone where the roots of most vegetables grow.

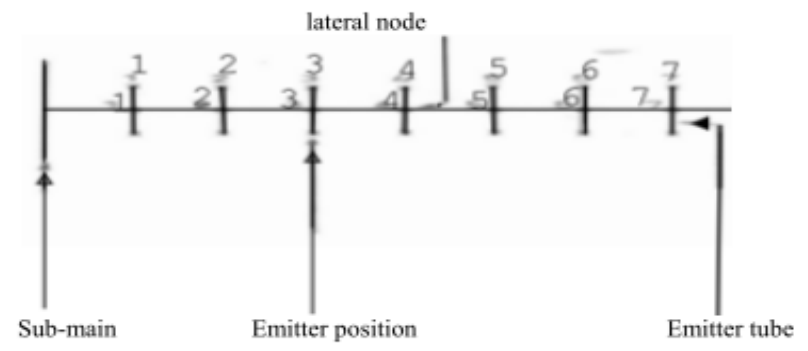

Figure 4: Lateral in the drip irrigation system layout.

Table 3: $\quad$ Standardized Moringa seed solution concentrations for wastewater treatment.

\begin{tabular}{|c|c|c|}
\hline MOSC, \% & Vol. of wastewater $\left(\mathrm{V}_{\mathrm{w}}\right), \mathrm{L}$ & Vol. of Moringa solution $\left(\mathrm{V}_{\mathrm{m}}\right), \mathrm{L}$ \\
\hline 0 & 1 & 0 \\
\hline 10 & 0.9 & 0.1 \\
\hline 20 & 0.8 & 0.2 \\
\hline 30 & 0.7 & 0.3 \\
\hline 40 & 0.6 & 0.4 \\
\hline
\end{tabular}

Source: Arku et al. [23]. 
Table 4: Methods used for evaluating soil and wastewater characteristics.

\begin{tabular}{|l|l|}
\hline \multicolumn{1}{|c|}{ Characteristics } & \multicolumn{2}{c|}{ Method/Equipment } \\
\cline { 1 - 2 } A. Chemical & \multicolumn{2}{|c}{ Combo Combined Electronic meter } \\
\cline { 1 - 2 } Electrical conductivity(EC), dS/m & Inductively-Coupled Optical Emission \\
\hline Sodium Adsorption Ratio (SAR) & Atomic Absorption Spectrometer (AAS). \\
\hline Boron $(\mathrm{B}), \mathrm{mg} / \mathrm{L}$ & Combo Combined Electronic meter \\
\hline $\mathrm{pH}$ & Titration using standard Silver Nitrate \\
\hline Chlorine $(\mathrm{Cl}), \mathrm{mg} / \mathrm{L}$ & Titration \\
\hline Bicarbonate $(\mathrm{HCO}), \mathrm{mg} / \mathrm{L}$ & AAS \\
\hline Nitrogen $(\mathrm{N}), \mathrm{mg} / \mathrm{L}$ & ICPOES \\
\hline Potassium $(\mathrm{K}), \mathrm{mg} / \mathrm{L}$ & ICPOES \\
\hline Phosphorus $(\mathrm{P}), \mathrm{mg} / \mathrm{L}$ & ICPOES \\
\hline Aluminium $(\mathrm{Al}), \mathrm{mg} / \mathrm{L}$ & ICPOES \\
\hline Cadmium $(\mathrm{Cd}), \mathrm{mg} / \mathrm{L}$ & ICPOES \\
\hline Lead $(\mathrm{Pb}), \mathrm{mg} / \mathrm{L}$ & \\
\hline B. Biological & Most Probable Number (MPN) \\
\hline Coliform count $(\mathrm{CC})$, cells $/ 100 \mathrm{~mL}$ & \\
\hline
\end{tabular}

\section{Results and discussion}

The experimental results obtained are presented in the following tables. The indices of wastewater quality before treatment in Table 5 show that the domestic wastewater was more polluted followed by the agricultural wastewater. The least polluted was the industrial wastewater, possibly because it was treated before discharge to the earthpond. In addition, the treated wastewater, as shown in Table 6 , had reasonable reductions when compared with the quality before treatment, implying the effect of the Moringa seed solution. The results of the soil particle-size analysis on the research farm using the soil triangle indicate a sandy loam soil (sand $-62.30 \%$, silt $-20.10 \%$ and clay $-17.60 \%$ ). The soil quality parameters after irrigation compared with the initial values at $0_{i}$ show progressive reductions, as shown in tables 7, 8 and 9, for the domestic, agricultural and industrial wastewaters respectively.

The coliform counts were virtually unobserved in all samples after irrigation for MOSC at $10 \%$ up to $40 \%$ due to the antimicrobial action of the Moringa solution. The chemical and biological parameters of the soil were considered of importance because they have a direct effect on the quality of the harvested produce, which might have been caused during the nutrient intake process at each developmental stage. In all cases, $0 \%$ (control) showed higher values of the quality parameters, possibly due to accumulations of the pollutants, while there were appreciable reductions observed in most of the soil quality parameters for the soils tested after irrigation as the Moringa seed solution concentrations were increased to $10,20,30$ and $40 \%$. In addition, the resultant quality parameters obtained in the soil did not show any severe threats to the selected crop based on the quality standards as recommended by The Food and Agriculture Organization, FAO [24] and WHO [25]. 
Table 5: Measured wastewater quality parameters before treatment.

\begin{tabular}{|c|c|c|c|}
\hline Characteristics & \multirow{2}{*}{$\begin{array}{c}\text { Domestic } \\
\mathrm{W}_{1}\end{array}$} & \multirow{2}{*}{$\begin{array}{l}\text { Agricultural } \\
\qquad \mathrm{W}_{2}\end{array}$} & \multirow{2}{*}{$\begin{array}{c}\text { Industrial } \\
\mathrm{W}_{3}\end{array}$} \\
\hline A. Chemical & & & \\
\hline Electrical conductivity $(\mathrm{EC}), \mathrm{dS} / \mathrm{m}$ & 0.78 & 1.20 & 1.23 \\
\hline Sodium Adsorption Ratio (SAR) & 1.12 & 1.54 & 1.18 \\
\hline Boron $(\mathrm{B}), \mathrm{mg} / \mathrm{L}$ & 0.44 & 1.80 & 1.28 \\
\hline $\mathrm{pH}$ & 8.56 & 5.60 & 6.98 \\
\hline Chlorine $(\mathrm{Cl}), \mathrm{mg} / \mathrm{L}$ & 10.42 & 10.90 & 6.20 \\
\hline Bicarbonate $\left(\mathrm{HCO}_{3}\right), \mathrm{mg} / \mathrm{L}$ & 7.98 & 7.60 & 6.41 \\
\hline Nitrogen $(\mathrm{N}), \mathrm{mg} / \mathrm{L}$ & 10.81 & 10.70 & 10.28 \\
\hline Potassium $(\mathrm{K}), \mathrm{mg} / \mathrm{L}$ & 21.45 & 20.80 & 18.42 \\
\hline Phosphorus $(\mathrm{P}), \mathrm{mg} / \mathrm{L}$ & 10.42 & 10.87 & 7.98 \\
\hline Aluminium (Al), mg/L & 0.56 & 1.56 & 0.55 \\
\hline Cadmium $(\mathrm{Cd}), \mathrm{mg} / \mathrm{L}$ & 0.03 & 0.21 & 0.06 \\
\hline Lead $(\mathrm{Pb}), \mathrm{mg} / \mathrm{L}$ & 0.02 & 1.96 & 0.03 \\
\hline B. Biological & & & \\
\hline Coliform count $(\mathrm{CC})$, cells $/ 100 \mathrm{~mL}$ & 1405 & 1571 & 1314 \\
\hline
\end{tabular}

Table 6: Measured wastewater quality parameters after treatment at $40 \% \mathrm{MOSC}$.

\begin{tabular}{|c|c|c|c|}
\hline Characteristics & Domestic & Agricultural & Industrial \\
\hline A. Chemical & $\mathrm{W}_{1}$ & $\mathrm{~W}_{2}$ & $\mathrm{~W}_{3}$ \\
\hline Electrical conductivity (EC), dS/m & 0.71 & 1.32 & 0.72 \\
\hline Sodium Adsorption Ratio (SAR) & 1.1 & 1.2 & 5.2 \\
\hline Boron $(\mathrm{B}), \mathrm{mg} / \mathrm{L}$ & 0.20 & 2.1 & 0.12 \\
\hline $\mathrm{pH}$ & 8.6 & 6.9 & 7.9 \\
\hline Chlorine $(\mathrm{Cl}), \mathrm{mg} / \mathrm{L}$ & 8.4 & 8.0 & 3.8 \\
\hline Bicarbonate $\left(\mathrm{HCO}_{3}\right), \mathrm{mg} / \mathrm{L}$ & 6.5 & 8.1 & 7.0 \\
\hline Nitrogen $(\mathrm{N}), \mathrm{mg} / \mathrm{L}$ & 6.0 & 8.2 & 6.2 \\
\hline Potassium $(\mathrm{K}), \mathrm{mg} / \mathrm{L}$ & 4.2 & 4.0 & 3.4 \\
\hline Phosphorus $(\mathrm{P}), \mathrm{mg} / \mathrm{L}$ & 0.4 & 0.1 & 0.2 \\
\hline Aluminium (Al), mg/L & 0.3 & 1.2 & 0.5 \\
\hline Cadmium $(\mathrm{Cd}), \mathrm{mg} / \mathrm{L}$ & 0.2 & 0.1 & 0.1 \\
\hline Lead $(\mathrm{Pb}), \mathrm{mg} / \mathrm{L}$ & 0.1 & 0.6 & 0.3 \\
\hline \multicolumn{4}{|l|}{ B. Biological } \\
\hline Coliform count (CC), cells $/ 100 \mathrm{~mL}$ & 120 & 124 & 92 \\
\hline
\end{tabular}


Table 7: Soil quality parameters before $\left(0_{\mathrm{i}}\right)$ and after irrigation with Moringatreated domestic wastewater.

\begin{tabular}{|c|c|c|c|c|c|c|}
\hline Parameter & \multirow[t]{2}{*}{$0_{\mathrm{i}}$} & \multicolumn{5}{|c|}{ MOSC, $(\%)$} \\
\hline A. Chemical & & 0 & 10 & 20 & 30 & 40 \\
\hline $\begin{array}{l}\text { Electrical conductivity (EC), } \\
\mathrm{dS} / \mathrm{m}\end{array}$ & 0.69 & 0.99 & 0.55 & 0.53 & 0.46 & 0.46 \\
\hline $\begin{array}{l}\text { Sodium Adsorption Ratio } \\
\text { (SAR) }\end{array}$ & 0.88 & 1.11 & 1.00 & 0.98 & 0.90 & 0.76 \\
\hline Boron $(B), m g / L$ & 0.63 & 1.48 & 0.45 & 0.53 & 0.56 & 0.60 \\
\hline $\mathrm{pH}$ & 6.50 & 6.00 & 6.34 & 6.67 & 7.20 & 7.10 \\
\hline Chlorine $(\mathrm{Cl}), \mathrm{mg} / \mathrm{L}$ & 8.28 & 9.86 & 9.98 & 10.20 & 10.12 & 10.00 \\
\hline Bicarbonate $\left(\mathrm{HCO}_{3}\right), \mathrm{mg} / \mathrm{L}$ & 4.8 & 6.50 & 6.70 & 8.97 & 10.20 & 11.23 \\
\hline Nitrogen $(\mathrm{N}), \mathrm{mg} / \mathrm{L}$ & 10.71 & 5.34 & 7.10 & 7.20 & 7.23 & 7.00 \\
\hline Potassium (K), mg/L & 6.5 & 7.24 & 7.25 & 2.18 & 1.66 & 1.65 \\
\hline Phosphorus $(\mathrm{P}), \mathrm{mg} / \mathrm{L}$ & 10.42 & 3.89 & 4.56 & 4.55 & 5.10 & 5.00 \\
\hline B. Biological & & & & & & \\
\hline $\begin{array}{l}\text { Coliform count }(\mathrm{CC}) \text {, } \\
\text { cells } / 100 \mathrm{~mL}\end{array}$ & 28 & 1530 & 12 & 0 & 0 & 0 \\
\hline
\end{tabular}

Table 8: $\quad$ Soil quality parameters before $\left(0_{\mathrm{i}}\right)$ and after irrigation with Moringatreated agricultural wastewater.

\begin{tabular}{|c|c|c|c|c|c|c|}
\hline Parameter & \multirow[t]{2}{*}{$0_{i}$} & \multicolumn{5}{|c|}{ MOSC, $(\%)$} \\
\hline A. Chemical & & 0 & 10 & 20 & 30 & 40 \\
\hline $\begin{array}{l}\text { Electrical conductivity } \\
\text { (EC), dS/m }\end{array}$ & 0.69 & 0.98 & 0.51 & 0.40 & 0.32 & 0.28 \\
\hline $\begin{array}{l}\text { Sodium Adsorption Ratio } \\
\text { (SAR) }\end{array}$ & 0.88 & 1.00 & 0.90 & 0.78 & 0.75 & 0.68 \\
\hline Boron (B), mg/L & 0.63 & 0.27 & 0.45 & 0.53 & 0.56 & 0.60 \\
\hline $\mathrm{pH}$ & 6.50 & 6.40 & 6.70 & 7.20 & 7.10 & 7.00 \\
\hline Chlorine $(\mathrm{Cl}), \mathrm{mg} / \mathrm{L}$ & 8.28 & 9.89 & 8.23 & 8.00 & 7.68 & 7.25 \\
\hline Bicarbonate $\left(\mathrm{HCO}_{3}\right), \mathrm{mg} / \mathrm{L}$ & 4.8 & 7.45 & 7.34 & 6.86 & 6.24 & 6.00 \\
\hline $\operatorname{Nitrogen}(\mathrm{N}), \mathrm{mg} / \mathrm{L}$ & 10.71 & 8.98 & 9.11 & 10.14 & 11.98 & 10.20 \\
\hline Potassium $(\mathrm{K}), \mathrm{mg} / \mathrm{L}$ & 6.5 & 8.51 & 7.45 & 7.25 & 6.90 & 6.50 \\
\hline Phosphorus (P), mg/L & 10.42 & 9.86 & 8.75 & 8.45 & 8.32 & 8.00 \\
\hline B. Biological & & & & & & \\
\hline $\begin{array}{l}\text { Coliform count }(\mathrm{CC}), \\
\text { cells } / 100 \mathrm{~mL}\end{array}$ & 28 & 1420 & 5 & 0 & 0 & 0 \\
\hline
\end{tabular}


Table 9: Soil quality parameters before $\left(0_{\mathrm{i}}\right)$ and after irrigation with Moringatreated industrial wastewater.

\begin{tabular}{|c|c|c|c|c|c|c|}
\hline Parameter & \multirow[t]{2}{*}{$0_{\mathrm{i}}$} & \multicolumn{5}{|c|}{ MOSC, $\%$} \\
\hline A. Chemical & & 0 & 10 & 20 & 30 & 40 \\
\hline $\begin{array}{l}\text { Electrical conductivity } \\
\text { (EC), dS/m }\end{array}$ & 0.69 & 0.71 & 0.32 & 0.29 & 0.20 & 0.18 \\
\hline $\begin{array}{l}\text { Sodium Adsorption Ratio } \\
\text { (SAR) }\end{array}$ & 0.88 & 1.11 & 1.00 & 0.98 & 0.79 & 0.60 \\
\hline Boron (B), mg/L & 0.63 & 0.97 & 0.45 & 0.53 & 0.56 & 0.60 \\
\hline $\mathrm{pH}$ & 6.50 & 7.40 & 6.70 & 6.20 & 7.10 & 7.10 \\
\hline Chlorine $(\mathrm{Cl}), \mathrm{mg} / \mathrm{L}$ & 8.28 & 10.32 & 9.76 & 8.34 & 4.67 & 3.00 \\
\hline Bicarbonate $\left(\mathrm{HCO}_{3}\right), \mathrm{mg} / \mathrm{L}$ & 4.8 & 5.60 & 5.00 & 4.32 & 1.80 & 1.32 \\
\hline Nitrogen $(\mathrm{N}), \mathrm{mg} / \mathrm{L}$ & 10.71 & 8.29 & 7.80 & 6.51 & 5.87 & 5.55 \\
\hline Potassium (K), mg/L & 6.5 & 7.20 & 6.00 & 5.12 & 5.00 & 5.00 \\
\hline Phosphorus $(\mathrm{P}), \mathrm{mg} / \mathrm{L}$ & 10.42 & 9.81 & 8.67 & 7.98 & 6.95 & 6.55 \\
\hline B. Biological & & & & & & \\
\hline $\begin{array}{l}\text { Coliform count (CC), } \\
\text { Cells } / 100 \mathrm{~mL}\end{array}$ & 28 & 1140 & 0 & 0 & 0 & 0 \\
\hline
\end{tabular}

\section{Conclusion}

From the results obtained, it can be established that the Moringa oleifera seed solution applied for treating the selected wastewaters had relative effects on most of the pollutants and succeeded in conditioning the wastewaters for crop irrigation. This study is therefore important for both water resources and soil management for an agriculturally oriented community, which will help in solving water pollution problems. Hence, it will minimize or eliminate waterborne diseases.

\section{References}

[1] Bove, F., Shim, Y. \& Zeitz, P., Drinking water contaminants and adverse pregnancy outcomes: a review. Environ. Health Perspect. 110 (Suppl 1), pp. 61-74, 2002.

[2] Kalibbala, H.M. (2007). Application of indigenous materials in drinking water treatment. Ph.D Thesis submitted to KTH Royal Institute of Technology, and Water Resources Engineering, Sweden.

[3] Diaz, A., Rincon, N., Escorihuela, A., Fernandez, N., Chacin, E. \& Forster, C.F., A preliminary evaluation of turbidity removal by natural coagulants indigenous to Venezuela. Process Biochemistry, 35 (3), pp. 391-395, 1999. 
[4] Özacar, M. \& Sengil, I.A., Effectiveness of tannins obtained from valonia as a coagulant aid for dewatering sludge. Wat. Res. 34 (4), pp. 1407-1412, 2000.

[5] Jahn, S.A.A., Drinking water from Chinese river: challenges of clarification. J. Water SRT-Aqua. 50, pp. 15-27, 2001.

[6] Bhole, A.G., Relative evaluation of a few natural coagulants. Journal SRT - Aqua. 44(6), pp. 284-290, 1995.

[7] Davikaran, R. \& Pillai, V.N.S., Flocculation of kaolinite suspension in water by chitosan. Wat. Res. 35 (16), pp. 3904-3908, 2001.

[8] Al-Samawi, A.A. \& Shokrala, E.M., An investigation into an indigenous natural coagulant. Enviro. Sci. Health. A31 (8), pp. 1881-1897, 1996.

[9] Sauveur, A.S \& Peprah, J.J.G., Moringa News. http://www.jatropha. de/expellers/, 2006.

[10] Foidl, N., Makkar, H.P.S. \& Becker, K., The potential of Moringa oleifera for agricultural and industrial uses. In: "The Miracle Tree/The Multiple Attributes of Moringa" (Ed. Lowell, J. Fuglie). CTA. USA, 2001.

[11] Muyibi, A.S. \& Evison, L.M., Moringa oleifera Seeds for Softening Hardwater. Wat. Res. Elsevier Science Ltd. Printed in Great Britain. 29 (4), pp. 1099-1105, 1995.

[12] Muyibi, A.S., Satiating thirst of millions in Nigeria. Application of processed Moringa oleifera seeds in drinking water treatment. 16th Public Lecture delivered at Abubakar Tafawa Balewa University, Bauchi, Nigeria on 3rd August, 2006.

[13] Nwaiwu, N.E. \& Ligmu, B., Studies on the effect of settling time on coliform reduction using Moringa oleifera seed powder. Journ. of Appl. Sci. and Sanitation. 6(3), pp. 1407-1412, 2011.

[14] Fuglie, L. \& Olivier, C., Illustrated brochure on water treatment with Moringa. http://www.moringanews.org/document/WaterGB, 2008.

[15] Sarpong, G. \& Richardson, P.C., Coagulation efficiency of Moringa oleifera for removal of turbidity and reduction of total coliform as compared to aluminum sulfate. African Journal of Agricultural Research. 5(21), pp. 2939-2944, 2010.

[16] Doerr, B., Moringa Water Treatment (An ECHO Technical Note). Educational Concerns for Hunger Organization (ECHO). Trees of Life Journal, 2005.

[17] Folklard, G. \& Sutherland, J., The use of Moringa oleifera seed as a natural coagulant for water and wastewater treatment. SIMPÓSIO INTERNACIONAL SOBRE TECNOLOGIASDE APOIO ÀGESTÃO DE RECURSOS HÍDRICOS Centro de Educação Empreendedora do SEBRAE João Pessoa/PB 10 a 13 de julho de 2001.

[18] Madsen, M., Schlundt, J. \& Omer, E.F., Effect of water coagulation by seeds of Moringa oleifera on bacterial concentrations. J. Trop. Med. Hyg. 90, pp. 101-109, 1987.

[19] Tauscher, B., Water treatment by flocculants compounds of higher plants. Plant Res. Dev. 40, pp. 56-70, 1994. 
[20] Schwarz, D., Water clarification using Moringa oleifera. Gate Information Service, Eschborn, Germany, 2000.

[21] Arku, A.Y., S.M. Musa \& Mofoke, A.L.E., Determination of water requirement and irrigation timing for Amaranthus hybridus in Maiduguri metropolis, north-eastern Nigeria. Proc. of the $4^{\text {th }}$ International conference on sustainable irrigation held at the University of South Australia, Adelaide from 11-13 December, 2012.

[22] Mofoke, A.L.E., Adewumi, J.K., Mudiare, O.J. \& Ramalan, A.A., Design, construction and evaluation of an affordable continuous-flow drip irrigation system. Journal of Applied Irrigation Science, 39 (2), pp. 253-269, 2004.

[23] Arku, A.Y., S.M. Musa \& Ahuchaogu, I.I., Treatment of wastewater using Moringa oleifera seed solution in Maiduguri, Nigeria. Proceedings of $34^{\text {th }}$ International conference organized by the Nigerian Institution of Agricultural Engineers (NIAE), held in Uyo, Akwa Ibom State, Nigeria, 21-24 $4^{\text {th }}$ October, 2013.

[24] Food and Agriculture Organization (FAO), Wastewater treatment and use in agriculture. FAO irrigation and drainage paper No. 47, 1992.

[25] World Health Organization (WHO). Guidelines for the safe use of wastewater, excreta and grey water: Wastewater use in agriculture (Volume 2). WHO: Geneva, pp. 219, 2006. 